Citation: E. Khemir, S. Chekali, A. Moretti, M.S. Gharbi, M.B. Allagui, S. Gargouri (2020) Impacts of previous crops on inoculum of Fusarium culmorum in soil, and development of foot and root rot of durum wheat in Tunisia. Phytopathologia Mediterranea 59(1): 187-201. doi: 10.14601/Phyto-10827

Accepted: March 5, 2020

Published: April 30, 2020

Copyright: (c) 2020 E. Khemir, S. Chekali, A. Moretti, M.S. Gharbi, M.B. Allagui, S. Gargouri. This is an open access, peer-reviewed article published by Firenze University Press (http:// www.fupress.com/pm) and distributed under the terms of the Creative Commons Attribution License, which permits unrestricted use, distribution, and reproduction in any medium, provided the original author and source are credited.

Data Availability Statement: All relevant data are within the paper and its Supporting Information files.

Competing Interests: The Author(s) declare(s) no conflict of interest.

Editor: Andy Tekauz, Cereal Research Centre, Winnipeg, MB, Canada.

\section{Research Paper \\ Impacts of previous crops on inoculum of Fusarium culmorum in soil, and development of foot and root rot of durum wheat in Tunisia}

\author{
Eya KHEMIR ${ }^{1,2, *}$, SAmira CHEKALI ${ }^{3}$, Antonio MORETTI ${ }^{4}$, Mohamed \\ Salah GHARBI ${ }^{1}$, Mohamed Bechir AllaGUI ${ }^{1}$, Samia GARGOURI ${ }^{1}$ \\ ${ }^{1}$ National Agronomic Institute of Research of Tunisia, University of Carthage, Tunis, \\ Tunisia \\ ${ }^{2}$ National Agronomic Institute of Tunisia, University of Carthage, Tunis, Tunisia \\ ${ }^{3}$ Regional Pole of Agricultural Research and Development of North-West, Kef, Tunisia \\ ${ }^{4}$ Institute of Sciences of Food Production, Research National Council (ISPA-CNR), Bari, Italy \\ ${ }^{*}$ Corresponding author: eya-khemir@hotmail.fr
}

\begin{abstract}
Summary. Fusarium foot and root rot (FFRR) of cereals, caused by Fusarium culmorum and other Fusarium spp., is one of the most important soil- and residue-borne diseases in Tunisia. Management of the disease relies primarily on cultural practices such as crop rotation. Impacts of previous crops on the population of F. culmorum in the soil, and the incidence and severity of FFRR in durum wheat, were evaluated under Tunisian farming systems. A field trial showed that break crops of faba bean and fenugreek reduced the amount of F. culmorum DNA in soil, by $58 \%$ (faba bean) and $65 \%$ (fenugreek), and decreased numbers of F. culmorum propagules per $\mathrm{g}$ of soil by $83 \%$ (faba bean) and $85 \%$ (fenugreek). Farm demonstration trials also showed that faba bean and vetch used as previous crops reduced F. culmorum inoculum in the soil. Non-cereal crops also reduced the incidence of F. culmorum present in durum wheat roots and stem bases. The greatest grain yields and thousand kernel weights were recorded when faba bean and vetch were used as previous crops, but were less where durum wheat was previously grown. There were strong correlations between inoculum level of F. culmorum in the soil and incidence of FFRR in the following year. Results obtained in the field trial were supported by those collected from three demonstration farm trials during two cropping seasons. This study demonstrated for the first time in Tunisia and the Mediterranean region that break crops are effective for reducing $F$. culmorum inoculum in the soil and decreasing the pathogen in wheat roots and stem bases. Inoculum levels in soil can predict the expression of the disease in the following year in Tunisian farming conditions. These results are likely to be useful for developing and implementing guidelines for the management of FFRR of durum wheat.
\end{abstract}

Keywords. Faba bean, fenugreek, legumes, rotation, vetch.

\title{
INTRODUCTION
}

In Tunisia, cereals and their by-products are the main sources of dietary calories, and are the common base of all diets and the historical base of the 
Mediterranean diet. The average per capita consumption of cereals in Tunisia is $184 \mathrm{~kg}$ per year (Slama et al., 2005; ONAGRI, 2016). Cereals are grown on approx. 1 million hectares of the agricultural land, with the number of the farmers involved estimated to be approx. 250,000 . About $63 \%$ of farmers are smallholders, each with land areas of less than 10 ha (Bachta, 2011; Anonymous 2, 2018). Fusarium foot and root rot (FFRR) has been recognized as one of the most important diseases of cereals in Tunisia since the 1970s (Ghodbane et al., 1974), and this disease is responsible for significant economic losses, especially in arid and semi-arid regions (Van Wyk et al., 1987; Bateman, 1993; Hollaway et al., 2013). Yield losses of up to $26 \%$ in durum wheat and $18 \%$ in barley have been recorded (Chekali et al., 2013).

FFRR is caused by a complex of fungal pathogens. The two most reported are Fusarium pseudograminearum (O'Donnell \& Aoki) (syn. F. graminearum group 1, Giberella coronicola) and F. culmorum (W. G. Sm.). F. pseudograminearum is the dominant species in several countries, including Australia (Burgess et al., 1975; Akinsanmi et al., 2004; Smiley et al., 2005), United States of America (Cook, 1980; Smiley and Patterson, 1996; Smiley et al., 2005) and New Zealand (Cromey et al., 2006), while F. culmorum is the dominant pathogen in Tunisia and the Mediterranean region (Cassini, 1981; Balmas,1994; Rossi et al., 1995; Mergoum et al., 2000; Gargouri et al., 2001).

FFRR is difficult to manage since F. culmorum can survive as hyphae in stubble residues of cereals (Cook, 1968; Bateman and Murray, 2001; Burgess, 2011; Khemir et al., 2018) and other grasses (Wallwork et al., 2004), and has the ability to persist as chlamydospores in soil (Sitton and Cook, 1981). This survival ability has major implications for designing strategies for effective disease management. Control of FFRR relies on agronomic management strategies, since in-crop fungicides are largely inefficient, and host resistance is limited (Burgess et al., 2001; Pereyra and Dill-Macky, 2004; Wisniewska and Kowalczyk, 2005).

The market situation in Tunisia has influenced the diversity of crops that are grown, where continuous wheat cropping and short crop rotations have become popular during the last 30 years. These cropping systems promote the increase of soil-borne diseases and resulting yield losses. In addition, durum wheat, which is highly susceptible to FFRR (Burgess et al., 2001), is the dominant crop, representing approx. $60 \%$ of the cereal growing area (Slama et al., 2005; Gharbi and Felah, 2013). In the context of climate change, this disease could become more important, especially as the Mediterranean region has been qualified as a "hot spot for climate change" (Giorgi, 2006; Vicente-Serrano, 2006; Anonymous 1, 2019). It is important, therefore, to consider the best cultural practices for FFRR control. Crop rotations with non-hosts such as legumes has been reported to efficiently control the disease in many countries including the United Kingdom (Bateman and Kwasana, 1999; Bateman and Murray, 2001), Australia (Felton et al., 1998; Kirkegaard et al., 2004; Evans et al., 2010) and South Africa (Lamprecht et al., 2006).

Very little research has been conducted in the Mediterranean basin, including Tunisia (Chekali et al., 2016), to evaluate the impacts of break crops on development of FFRR. Fenugreek, an annual legume that grows well in Mediterranean climates (Duke et al., 1981), and which has demonstrated strong insecticidal, nematicidal and antifungal activity (Pemonge et al., 1997; Zia et al., 2001; Evidente et al., 2007; Haouala et al., 2008; Omezzine et al., 2014), has not been evaluated for reducing F. culmorum levels in soil, and its impacts on the disease. Very few studies have focused on monitoring F. culmorum soil inoculum under different cropping systems (McKenzie and Taylor, 1983; Evans et al., 2010).

The present study aimed to assess: i) the potential benefits of previous crops for reducing F. culmorum populations in the soil; ii) the impacts of previous crops on the incidence and severity of FFRR on stems and roots of durum wheat; and iii) the relationships between preplanting inoculum of F. culmorum and FFRR disease expression and grain yields.

\section{MATERIALS AND METHODS}

\section{Site characteristics and cultural practices}

To understand the effect of previous crops on populations of F. culmorum in the soil and incidence of FFRR in durum wheat, a field trial and three demonstration trials were established during the cropping seasons 2012/13, 2013/14 and 2014/15, in Northwest Tunisia.

\section{Field trial}

The field trial was carried out in a farm field located at Bou Salem (N36 53.012 E9 31.251). The area has a typical Mediterranean climate (Köppen, 1936), with hot summers and cold, wet winters. The monthly rainfall during the three cropping seasons at Bou Salem is summarized in Table 1, where the 10 -yr annual average rainfall is approx. $500 \mathrm{~mm}$.

The trial was established in $2012 / 13$ as a randomized complete block design (RCBD) with three crop- 
Table 1. Monthly rainfall (mm) recorded during the 2012/2013, 2013/14 and 2014/15 cropping seasons at Bou Salem, Tunisia.

\begin{tabular}{|c|c|c|c|c|c|c|c|c|c|c|c|c|c|}
\hline Cropping season & Sep. & Oct. & Nov. & Dec. & Jan. & Feb. & Mar. & Apr. & May. & Jun. & Jul. & Aug. & Total \\
\hline $2012 / 13$ & 62 & 67 & 22 & 27 & 50 & 64 & 22 & 28 & 4 & 0 & 10 & 31 & 387 \\
\hline $2013 / 14$ & 14 & 45 & 118 & 44 & 81 & 23 & 82 & 24 & 47 & 4 & 0 & 0 & 482 \\
\hline $2014 / 15$ & 1 & 36 & 33 & 103 & 118 & 128 & 79 & 2 & 18 & 1 & 0 & 21 & 540 \\
\hline 10 years means $(2006 / 2015)$ & 35 & 58 & 50 & 61 & 73 & 60 & 69 & 46 & 29 & 8 & 1 & 9 & 499 \\
\hline
\end{tabular}

Source: National Institute of Meteorology.

Table 2. Monthly rainfall (mm) recorded during the 2012/2013, 2013/14 and 2014/15 cropping seasons at Fernana, Tunisia.

\begin{tabular}{|c|c|c|c|c|c|c|c|c|c|c|c|c|c|}
\hline Cropping season & Sep. & Oct. & Nov. & Dec. & Jan. & Feb. & Mar. & Apr. & May. & Jun. & Jul. & Aug. & Total \\
\hline $2012 / 13$ & 89 & 106 & 22 & 138 & 149 & 221 & 25 & 28 & 23 & 0 & 0 & 1 & 802 \\
\hline $2013 / 14$ & 23 & 18 & 298 & 82 & 91 & 46 & 109 & 70 & 32 & 9 & 4 & 2 & 784 \\
\hline $2014 / 15$ & 45 & 95 & 35 & 138 & 115 & 120 & 65 & 40 & 40 & 7 & 2 & 1 & 703 \\
\hline 15 years means $(2001 / 2015)$ & 31 & 78 & 81 & 126 & 128 & 120 & 82 & 83 & 32 & 12 & 3 & 5 & 781 \\
\hline
\end{tabular}

Source: National Institute of Meteorology.

ping sequences and four replications. An area of 7,500 $\mathrm{m}^{2}$ was divided into four blocks. Each block was subdivided into three plots (each of $12 \times 50 \mathrm{~m}$ ) which were sown with durum wheat (Triticum durum) var. 'Karim', faba bean (Vicia faba) var. 'Bachar' or fenugreek (Trigonella foenum-graecum) var 'Rihana'. The impacts of previous crops were assessed during the two following cropping seasons of 2013/14 and 2014/15. Durum wheat was sown at the recommended rate of $150 \mathrm{~kg}$ $\mathrm{ha}^{-1}$; faba bean was sown at $140 \mathrm{~kg} \mathrm{ha}^{-1}$ and fenugreek at $35 \mathrm{~kg} \mathrm{ha}^{-1}$. All these crops were seeded in early to mid-November of each year. Diammonium phosphate (P) $\left(150 \mathrm{~kg} \mathrm{ha}^{-1}\right)$ was applied with seed (Zadoks growth stage (ZGS) 1; Zadoks et al. 1974), and ammonium nitrate fertilizer $(\mathrm{N})\left(150 \mathrm{~kg} \mathrm{ha}^{-1}\right)$ was applied at tillering (ZGS 21) and at stem elongation (ZGS 32). For uniform suppression of grass weeds in the faba bean and fenugreek plots, clethodim (Select super ${ }^{\circledR}$ ) was applied at $1 \mathrm{~L} \mathrm{ha}^{-1}$ post-emergence of grass weeds from the 3-leaf stage of the crop plants.

\section{Demonstration trials}

Demonstration trials were established in three farmer's fields $\left(36^{\circ} 37^{\prime} 29.28^{\prime} \mathrm{N}, 8^{\circ} 42^{\prime} 04.56^{\prime} \mathrm{E} ; 36^{\circ} 36^{\prime} 47.56^{\prime} \mathrm{N}\right.$, $8^{\circ} 34^{\prime} 39.42^{\prime} \mathrm{E}$ and $36^{\circ} 37^{\prime} 01.10^{\prime} \mathrm{N}$. $8^{\circ} 40^{\prime} 35.90^{\prime} \mathrm{E}$ ) at Fernana. This region is also characterized by hot summers and cold, wet winter, but with greater annual rainfall than at the field trial site. The monthly rainfall during the three cropping seasons is summarized in Table 2, and the $15 \mathrm{y}$ average rainfall was approx. $780 \mathrm{~mm}$ at this location.
In 2012/13, an area of $3,000 \mathrm{~m}^{2}$ at each farm was divided into three plots, which were each sown with faba bean (Vicia faba) var. 'Bachar', durum wheat (Triticum durum) var. 'Karim' or a local variety of vetch (Vicia sativa). The plots were $10 \mathrm{~m}$ wide and $100 \mathrm{~m}$ long. The effects of previous crops were evaluated during the two subsequent cropping seasons (2013/14 and 2014/15). These trials were direct seeded (without tillage) to retain uniform and high inoculum levels of $F$. culmorum at the beginning of the study. The three previous crops were applied according to common farmer practices. Durum wheat was seeded at $150 \mathrm{~kg} \mathrm{ha}^{-1}$, faba bean at $130 \mathrm{~kg} \mathrm{ha}^{-1}$ and vetch at $100 \mathrm{~kg} \mathrm{ha}^{-1}$. Diammonium phosphate $(\mathrm{P})$ $\left(150 \mathrm{~kg} \mathrm{ha}^{-1}\right)$ was applied with seed (Zadoks growth stage (ZGS) 1; Zadoks et al. 1974), and ammonium nitrate fertilizer (N) (150 kg ha-1) was applied at tillering (ZGS 21) and at stem elongation (ZGS 32).

To control annual grass weeds, glyphosate $\left(3 \mathrm{~L} \mathrm{ha}^{-1}\right)$ was applied prior to sowing of durum wheat and mésosulfuron-méthyl $\left(\right.$ Mesomax $\left.^{\circ}\right)+$ iodosulfuron + méfenpyr $\left(\right.$ Amilcar $\left.{ }^{\circ}\right)\left(1 \mathrm{~L} \mathrm{ha}^{-1}\right)$ was applied in January 2014 and in January 2015 . The faba bean plots received simazine (1.5 $\left.\mathrm{L} \mathrm{ha}^{-1}\right)$ and clethodim (Select Super $\left.{ }^{\oplus}\right)\left(1 \mathrm{~L} \mathrm{ha}^{-1}\right)$ at postemergence of the grassy weeds.

Fusarium culmorum inoculum density

Soil sampling

Soil samples were collected in July 2013, following the crop sequence treatments from the 12 plots of 
the field trial at Bou Salem, and the three plots from each of the demonstration trials at Fernana. One hundred soil cores, including any plant residus, were taken within each plot to a depth of $100 \mathrm{~mm}$, using a $15-\mathrm{mm}$ diam. Accucore corer (Spurr Soil Probes), and were then bulked to provide a single sample for each plot. The samples were air-dried for several days. Dry soil (500 g) for each plot was sent to the South Australian Research and Development Institute (SARDI), Adelaide, Australia, for assays of F. culmorum DNA ('Predicta B' Soil Testing Service). The remaining soil from each plot was used for soil dilution plating (below).

\section{Soil dilution plating}

This was carried out to estimate populations of $F$. culmorum (Cook, 1980), following the procedure of Snyder and Nash (1968), with modifications as described by Bateman and Coskun (1995), Bateman et al., (1998) and Bateman and Murray (2001). Briefly, $10 \mathrm{~g}$ of soil from each plot were added to $100 \mathrm{~mL}$ of $0.1 \%$ water agar and mixed thoroughly for $30 \mathrm{sec}$. Further dilution series were made using $1 \mathrm{~mL}$ aliquots from the starting suspension. An aliquot of $1 \mathrm{~mL}$ of the final dilution (1/100, based on premilary tests) was transferred to each of five Petri dishes containing Peptone-PCNB agar medium. This medium contained $15 \mathrm{~g}$ Difco peptone, $20 \mathrm{~g}$ agar, $1 \mathrm{~g} \mathrm{KH}_{2} \mathrm{PO}_{4}$, $0.5 \mathrm{~g} \mathrm{MgSO}_{4} 7 \mathrm{H}_{2} \mathrm{O}, 1 \mathrm{~g}$ pentachloronitrobenzene (PCNB), $100 \mathrm{mg} \mathrm{L}^{-1}$ streptomycin sulfate and $80 \mathrm{mg} \mathrm{L}^{-1}$ neomycin. Aliquots were dispersed by circular agitation of the Petri dishes (Steinkellner and Langer, 2004). The Petri dishes were incubated at $20^{\circ} \mathrm{C}$ for $5-7 \mathrm{~d}$ with a $16 \mathrm{~h} \mathrm{light} / 8 \mathrm{~h}$ dark regime. Fusarium culmorum was identified morphologically according to Leslie and Summerell (2006).

To confirm fungal identifications, some colonies were transferred to $1 / 4$ strength potato dextrose agar (PDA) and then to carnation leaf agar (CLA). Amounts of F. culmorum in the soil samples were expressed as the numbers of colony forming units per gram of air-dried soil (CFU g-1 soil).

$\mathrm{CFU} \mathrm{g^{-1 }}$ was calculated using the formula:

CFU $\mathrm{g}^{-1}=\frac{\text { Number of colonies } \times \text { dilution factor }}{\text { Volume of culture plate }}$

With dilution factor $=10^{2}$, and volume of culture plate $=1 \mathrm{~mL}$.

\section{Quantitative real-time polymerase chain reaction ( $q P C R$ )}

The amount of F. culmorum DNA present in soil from each plot was evaluated, after applying the crop sequence treatments (July 2013). Soil samples were submitted to the SARDI Root Disease Testing Service. This includes a suite of tests for the quantification of F. culmorum DNA in soil. QPCR assays using rDNA (TaqMan) probe sequences specific to $F$. culmorum were made for the total pathogen DNA extracted from the soil. Levels of F. culmorum DNA in soil can be related to disease risk in the following crop year (Hogg et al., 2007). Extraction protocols and analyses of DNA from soil were done according to Ophel-Keller et al. (2008). Inoculum concentrations of DNA per gram of soil were expressed in pictograms.

\section{Pathogen isolation and disease incidence}

During the 2013/14 and 2014/15 seasons, 50 plants of durum wheat were collected randomly along a $\mathrm{W}$-shaped transcript, from each of the 12 plots of the field trial, and from the nine plots of the three demonstration trials, at the durum wheat anthesis stage (ZGS 85). The incidence of FFRR was calculated as the frequency of isolation of F. culmorum, separately from roots or stem bases.

Stem base sections and root sections $(2-3 \mathrm{~mm}$ length) were surface-sterilized with $70 \%$ ethanol for 15 $\mathrm{s}$, followed by $3 \%$ sodium hypochlorite for $1 \mathrm{~min}$, and then rinsed three times with distilled water, and were then air-dried on sterile filter paper. Five sections from each sample were then plated onto $1 / 4$ strength PDA containing $20 \mathrm{~mL} \mathrm{~L}^{-1}$ streptomycin sulfate $\left(100 \mathrm{mg} \mathrm{L}^{-1}\right)$ and $12 \mathrm{~mL} \mathrm{~L}^{-1}$ neomycin sulfate $\left(80 \mathrm{mg} \mathrm{L}^{-1}\right)$ in Petri dishes. The plates were incubated up to 7 days at $25^{\circ} \mathrm{C}$ in a 12 $\mathrm{h}$ light/12 h dark regime. Hyphae of Fusarium spp. were subsequently transferred onto CLA to promote conidium production. Fusarium culmorum was identified using morphological criteria, according to Leslie and Summerell (2006).

\section{Disease severity}

FFRR disease severity was assessed only during the 2014/15 cropping season in the three farm demonstration trials, at the durum wheat anthesis stage (ZGS 85). Severity of F. culmorum was evaluated by measuring surface of stem bases showing browning. Fifty durum wheat plants were randomly removed from each plot and scored using a scale 0 to 3 , where: $0=$ no browning (no visible symptoms); $1=0.1$ to $1.9 \mathrm{~cm}$ extent of browning; $2=2$ to $3.9 \mathrm{~cm}$ of browning; and $3=>4 \mathrm{~cm}$ browning.

Ratings were converted to severity indices using the following formula: 
$\begin{aligned} & \text { Severity } \\ & \text { index }\end{aligned}=\frac{((0) \times(\mathrm{n} 0)+(1) \times(\mathrm{n} 1)+(2) \times(\mathrm{n} 2)+(3) \times(\mathrm{n} 3))}{\mathrm{N}}$

Where: $\mathrm{N}=$ number of evaluated plants; $\mathrm{n}_{0}=$ number of plants in class $0 ; \mathrm{n}_{1}=$ number of plants in class $1 ; \mathrm{n}_{2}=$ number of plants in class 2 ; and $\mathrm{n}_{3}=$ number of plants in class 3.

\section{Yield parameters}

Grain yields of durum wheat, subjected to different crop rotations, were assessed from the three demonstration trials in the 2013/14 and 2014/15 cropping seasons. The yields $\left(\mathrm{kg} \mathrm{ha}^{-1}\right)$ were based on harvesting all of the grain from each plot.

\section{Statistical analyses}

Field trial

The trial was arranged in a randomized complete block design (RCBD) with four replicates. All data were subjected to analysis of variance (ANOVA) using 'SPSS Statistics version 20' software published by 'IBM Crop 2011'. The year and previous crop were considered as main factors. Means comparisons were performed using the Student's LSD test (at $P=0.05$ or $P=0.01$ ).

Regression analyses used Pearson's correlation test, to identify possible associations between the incidence of F. culmorum isolated from stem bases and roots (2013/14 cropping season data) and the amounts of F. culmorum in the soil (DNA and CFU) left after each treatment, measured at plant maturity in July 2013.

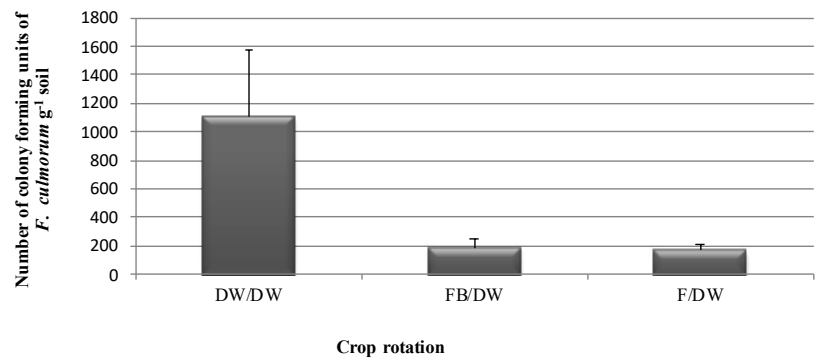

Figure 1. Mean numbers of colony forming units of Fusarium culmorum $\mathrm{g}^{-1}$ of soil, estimated by dilution plating, sampled from the experimental trial at Bou Salem, Tunisia, after different crop rotations. Error bars are $2 \times$ standard deviations. $\mathrm{DW}=$ durum wheat, $\mathrm{FB}=$ faba bean, $\mathrm{F}=$ fenugreek.
Demonstration trials

Regression analyses were carried out (as above), to identify possible correlations between $F$. culmorum DNA content in soil (determined by qPCR), the number of CFU of F. culmorum per gram of soil (determined by soil dilution plating) and the incidence of F. culmorum isolations from stem bases and roots of durum wheat (2013/14 cropping season data). In addition, regression analysis was used to identify possible association between FFRR expression and grain yields from subsequent durum wheat crops.

\section{RESULTS}

Fusarium culmorum inoculum in the soil

Soil dilution plating and morphological identification revealed several Fusarium species from the soil samples. These included $F$. acuminatum, $F$. avenaceum, F. culmorum, F. compactum, F. equiseti, F. oxysporum and F. solani. However, F. culmorum was by far the dominant pathogenic species in the samples. The DNA analyses conducted for detection of the two recognized pathogenic species, F. culmorum and F. pseudograminearum, showed the presence of only F. culmorum in the samples.

\section{Field trial}

Soil dilution plating revealed the presence of $F$. culmorum in all 12 plots of the field trial at Bou Salem. ANOVA of data from the trial revealed that the number of CFU of F. culmorum in the upper $10 \mathrm{~cm}$ soil layer was significantly $(P=0.002)$ affected by the different break crops. Faba bean and fenugreek used as previous crops, $v s$. durum wheat monoculture, reduced the number of F. culmorum propagules in soil by $83 \%$ for faba bean and $85 \%$ for fenugreek (Figure 1). The number of propagules ranged from 133 to 1,733 CFU g-1 of soil, with a mean of 1100 for durum wheat, 183 for faba bean and 166 for fenugreek. DNA analyses confirmed the presence of F. culmorum in soil from the 12 plots of the field trial. The amounts of DNA of the pathogen were significantly $(P=0.004)$ different among previous crop treatments, ranging from 27 to 212 pg DNA g-1 of soil. Overall, the amounts of F. culmorum DNA in the soil were decreased by $58 \%$ following faba bean and by $65 \%$, following fenugreek. The greatest amounts of F. culmorum DNA occurred in the treatment where durum wheat was cultivated in monoculture, and here was no statistically 


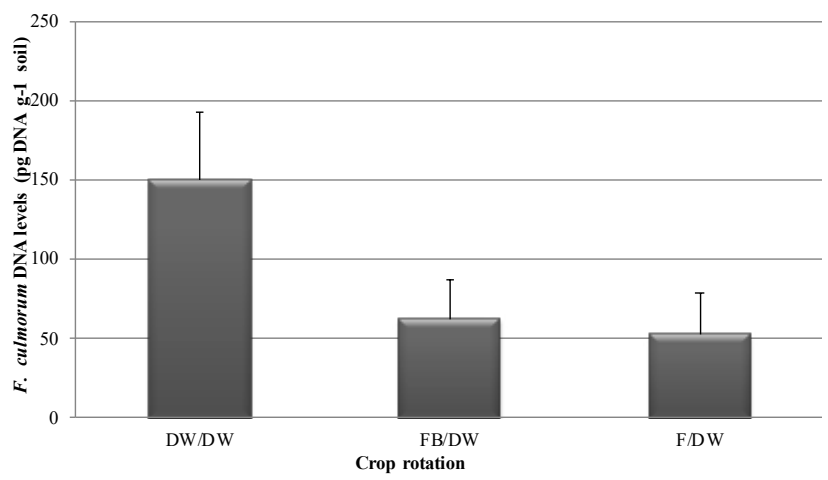

Figure 2. Amounts of Fusarium culmorum DNA in soil (pg DNA ${ }^{-1} \mathrm{~g}$ of soil) 1 year after different crop rotations from the experimental field trial at Bou Salem, Tunisia. Error bars are $2 \times$ standard deviations. DW: durum wheat, $\mathrm{FB}=$ faba bean, $\mathrm{F}=$ fenugreek.

significant difference in DNA amounts between the two legume treatments (Figure 2).

Soil dilution plating and qPCR both showed greater amounts of $F$. culmorum in soil following a previous durum wheat crop, compared to previous faba bean or fenugreek crops. Pearson's correlation test showed that F. culmorum DNA concentration (pg DNA g ${ }^{-1}$ soil) was correlated $(\mathrm{r}=0.92 ; P<0.001)$ with the number of propagules of this fungus (CFU g ${ }^{-1}$ soil) detected in the soil 1 year after treatment.

\section{Demonstration trials}

Based on soil dilution plating, propagules of F. culmorum in the soil were more abundant after wheat (average of 866 propagules $\mathrm{g}^{-1}$ of soil) compared to vetch (358 propagules $\mathrm{g}^{-1}$ of soil) or faba bean (289 propagules $\mathrm{g}^{-1}$ of soil) (Table 3). Thus, faba bean and vetch, used as previous crops, reduced the number of F. culmorum propagules in soil by $66 \%$ after faba bean and $58 \%$ after vetch, compared to durum wheat monoculture. In addition, the results indicated that F. culmorum propagules were less abundant after faba bean as a previous crop compared to vetch.
The DNA analyses showed greater amounts of $F$. culmorum DNA in soil from Farm 1 and 2 compared to Farm 3 (Table 3). Based on real-time qPCR, the amount of DNA of F. culmorum was less following a legume compared to wheat at Farms 1 and 2. However, at Farm 3, where the DNA amounts were low in all cases, there were no differences in F. culmorum DNA between the different previous crops. Based on the SARDI risk assessment protocol, DNA amounts for all plots at Farm 3 were classified as leading to low risk of subsequent crop damage.

Overall, for the 12 plots of the field trial and the six plots of the demonstration trials at Farms 1 and 2, legumes used as previous crops reduced the inoculum of F. culmorum, as detected by $\mathrm{qPCR}$ and by soil dilution plating.

\section{Disease assessments}

A total of 4,200 stems and roots were examined to determine the impacts of crop sequence on soil-borne diseases of cereals in the field and demonstration trials. Visual assessments revealed evidence of take-all, eyespot and FFRR. Only the results for previous crop effects on FFRR development are presented here.

\section{Field trial}

Incidence of infection by $F$. culmorum in durum wheat was greater in durum wheat stem bases than in roots. Statistical analyses showed that there was a difference $(P=0.047)$ between the two growing seasons (2013/14 and 2014/15) for incidence of F. culmorum recovered from durum wheat stem bases. No significant difference was detected in the incidence of F. culmorum recovered from wheat roots during these two cropping seasons (Figure 3).

ANOVA of data from the field trial revealed that there was a highly significant $(P<0.001)$ effect of previous crop on the incidence of FFRR infection of stem bases and roots of durum wheat. Fenugreek or faba

Table 3. Number of colony forming units (CFU g ${ }^{-1}$ of soil), levels of DNA (pg DNA g ${ }^{-1}$ soil) of Fusarium culmorum 1 year after treatment at three demonstration trial sites, and risk of resultant crop losses (Predicta ${ }^{\oplus} \mathrm{B}$ test).

\begin{tabular}{|c|c|c|c|c|c|c|c|c|c|}
\hline \multirow{2}{*}{ Previous crop rotation } & \multicolumn{3}{|c|}{ Site 1} & \multicolumn{3}{|c|}{ Site 2} & \multicolumn{3}{|c|}{ Site 3} \\
\hline & $\mathrm{CFU} \mathrm{g}^{-1}$ & pg DNA g ${ }^{-1}$ & Risk & $\mathrm{CFU} \mathrm{g}^{-1}$ & pg DNA g ${ }^{-1}$ & Risk & $\mathrm{CFU} \mathrm{g}^{-1}$ & pg DNA g ${ }^{-1}$ & Risk \\
\hline Durum wheat/durum wheat & 1071 & 104 & medium & 928 & 328 & high & 600 & 14 & low \\
\hline Durum wheat/vetch & 142 & 41 & low & 500 & 150 & medium & 433 & 44 & low \\
\hline Durum wheat/faba bean & 0 & 14 & low & 500 & 163 & medium & 366 & 50 & low \\
\hline
\end{tabular}




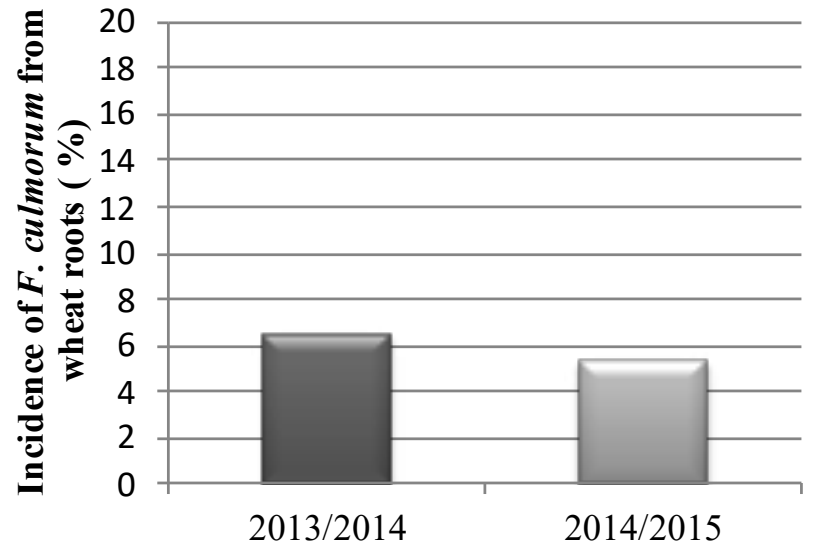

Cropping season

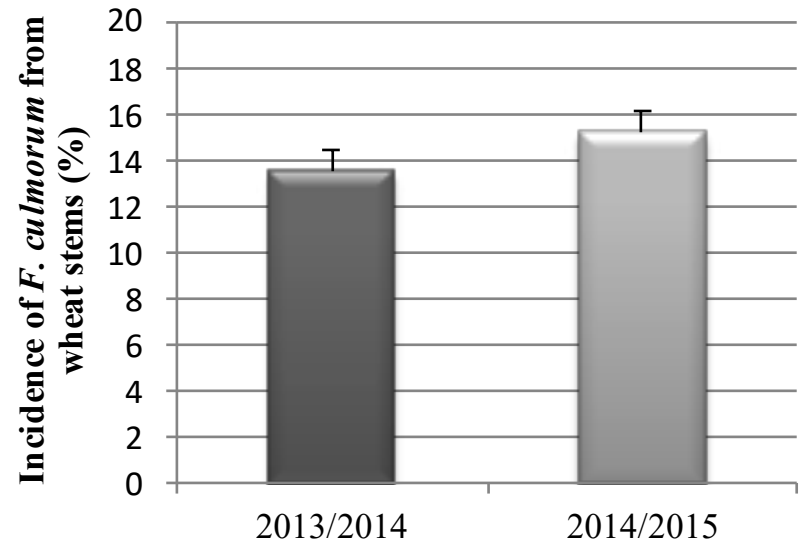

Cropping season

Figure 3. Mean incidence of Fusarium culmorum isolations from durum wheat roots (A) and stem bases (B) during two cropping seasons, at the Bou Salem,Tunisia, field trial. Error bars are $2 \times$ standard deviations.

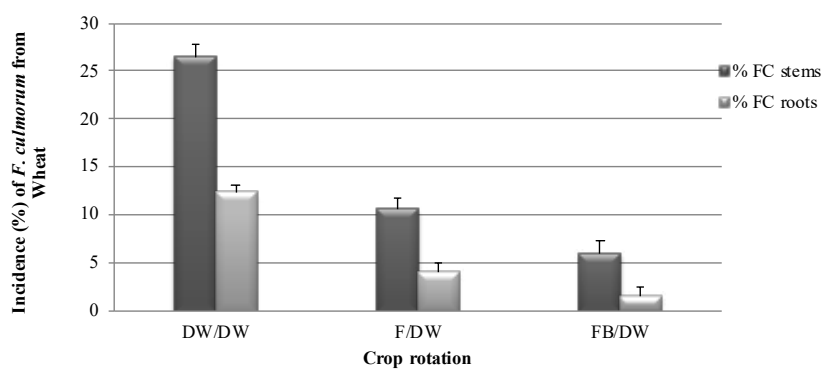

Figure 4. Mean incidence of Fusarium culmorum infection on wheat stem bases and roots as affected by different previous crops (DW = durum wheat; $\mathrm{F}=$ fenugreek; $\mathrm{FB}=$ faba bean), at the Bou Salem, Tunisia, field trial in the 2013/14 and 2014/15 cropping seasons. Error bars are $2 \times$ standard deviations.

bean used as the previous crop decreased the incidence of $F$. culmorum affected durum wheat roots more than $3 \times$ for fenugreek and $9 \times$ for faba bean, compared to durum wheat. Similarly, fenugreek and faba bean decreased the incidence of $F$. culmorum in durum wheat stem bases, by more than $3 \times$ for fenugreek and $5 \times$ for faba bean. Data analyses showed that the incidence of infection by $F$. culmorum on durum wheat stem bases and roots was least $(P<0.001)$ when faba bean was the previous crop (Figure 4).

\section{Demonstration trials}

Data from the three demonstration trials showed that the presence of $F$. culmorum in durum wheat roots and stem bases when they were sampled dur-

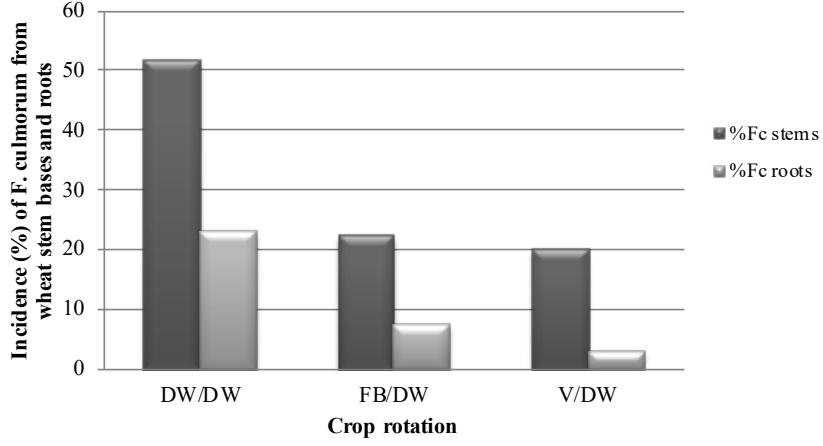

Figure 5. Mean incidence of Fusarium culmorum $(\mathrm{Fc})$ from durum wheat stem bases and roots from three demonstration trials, after previous crops of durum wheat faba bean and vetch.

ing the 2013/14 and 2014/15 cropping seasons. Assessments of development of FFRR showed that stem bases were much more likely to be infected by F. culmorum than roots. Faba bean and vetch, used as previous crops, resulted in a less isolation incidence of F. culmorum than for durum wheat monoculture. Compared to durum wheat, the mean reduction in F. culmorum incidence after faba bean was $59 \%$ in stem bases and $68 \%$ in roots, and after vetch was $62 \%$ in stem bases and $87 \%$ in roots (Figure 5).

FFRR severity was evaluated only in spring 2015 (2014/15 cropping season). Compared to durum wheat monocropping, vetch used as the previous crop reduced disease severity by $80 \%$ and faba bean as the previous crop reduced severity by $50 \%$ (Figure 6). 


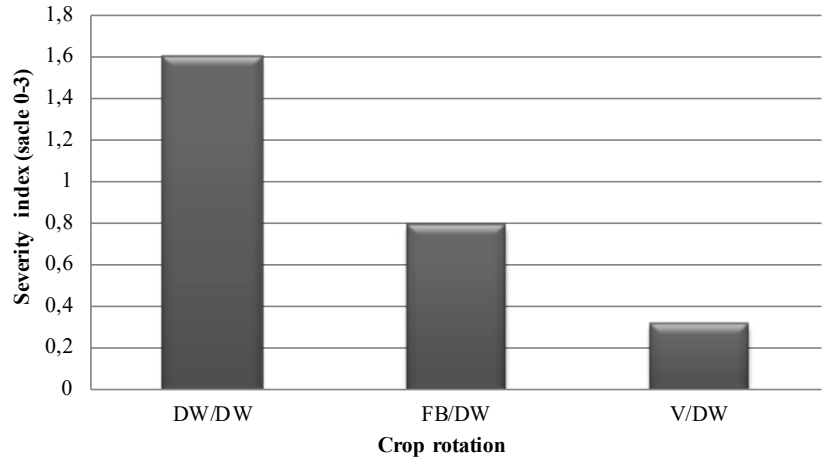

Figure 6. Mean durum wheat foot and root rot severity indices for wheat grown after durum wheat (DW), faba bean (FB) or vetch (V) at the Fernana demonstration trials during the 2014/2015 cropping season.

Relationships between Fusarium culmorum inoculum density in soil and development of FFRR

Field trial

According to Pearson's correlation test, the amounts of F. culmorum DNA detected in soil samples 1 year after treatment were positively correlated with the incidence of $F$. culmorum, durum wheat roots $\left(\mathrm{R}^{2}=0.56\right.$, $P=0.005)$ and in stem bases $\left(\mathrm{R}^{2}=0.80, P=0.001\right)$ for wheat grown in the following year (Figure 7).

The association between pre-planting inoculum concentrations, indicated by F. culmorum CFU g-1 of soil, and disease expression, indicated by incidence of $F$. culmorum in wheat roots, was significantly positive $\left(\mathrm{R}^{2}=0.58, P=0.004\right)$ (Figure $\left.7 \mathrm{~A}\right)$. This was also true for this relationship in stem bases $\left(\mathrm{R}^{2}=0.83, P=\right.$ 0.000) (Figure 7B).

\section{Demonstration trials}

Inoculum levels of F. culmorum detected in the soil after each treatment, as determined by soil dilution plating, were positively correlated with incidence of F. culmorum in wheat roots $\left(\mathrm{R}^{2}=0.66\right)$ and stem bases $\mathrm{R}^{2}=$ 0.64 (Figure $8, \mathrm{~A}$ and $\mathrm{B}$ ). In addition, a positive relationship was observed between the amounts of $F$. culmorum DNA and the incidence of $F$. culmorum in wheat roots $\left(\mathrm{R}^{2}=0.65\right)$ and stem bases $\left(\mathrm{R}^{2}=0.7\right)$ after each treatment (Figure 8, A and B).

\section{Grain yields}

The greatest durum wheat grain yield $\left(3,833 \mathrm{~kg} \mathrm{ha}^{-1}\right)$ was recorded when vetch was the previous crop, followed by faba bean $\left(3,583 \mathrm{~kg} \mathrm{ha}^{-1}\right)$ and durum wheat $\left(3,239 \mathrm{~kg} \mathrm{ha}^{-1}\right)$ (Figure 9). Regression analyses showed a negative correlation between grain yields $\left(\mathrm{kg} \mathrm{ha}^{-1}\right)$ and $F$. culmorum incidence on durum wheat stem bases (Figure 10) $(\mathrm{r}=-0.74)$, and grain yields FFRR severity indices $(\mathrm{r}$ $=-0.56$ ) (Figure 11).
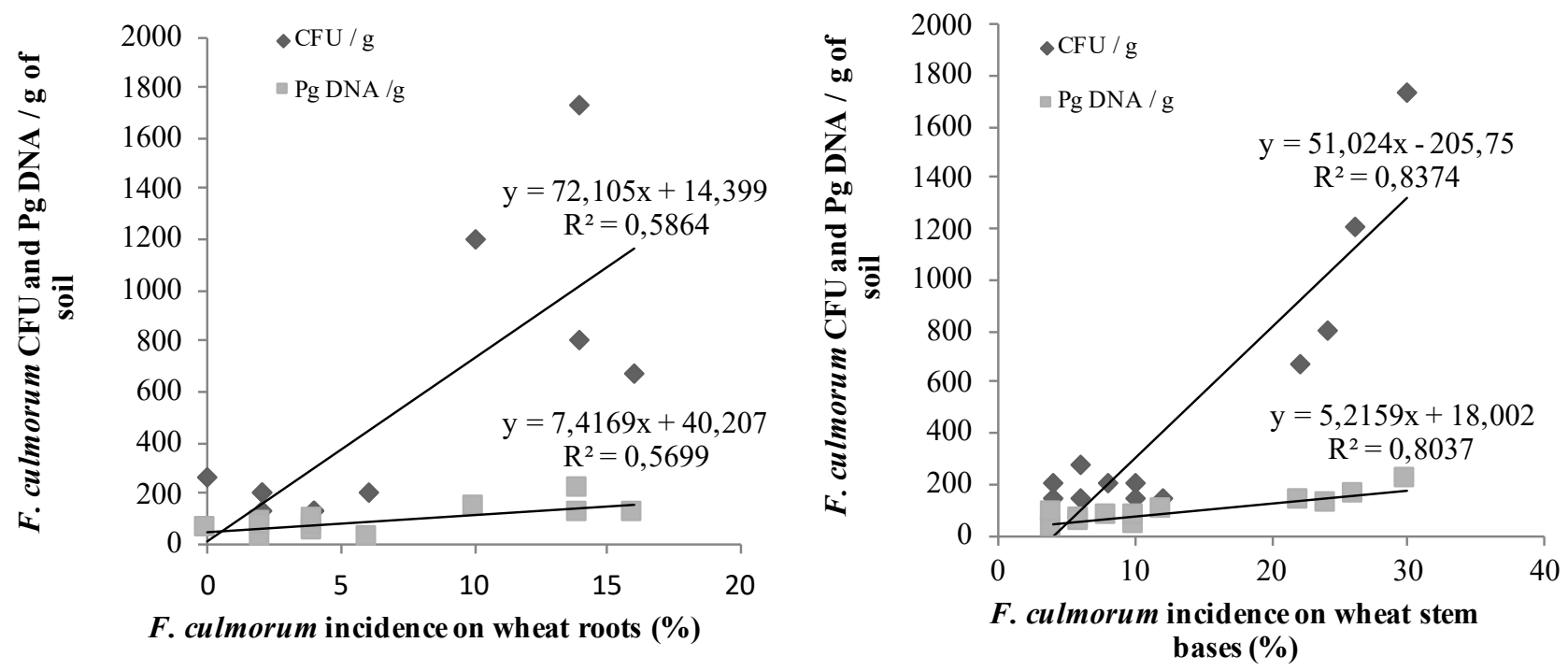

Figure 7. Correlations (Pearson's correlation test) between Fusarium culmorum on wheat roots (A) and stem bases (B) and amounts of $F$. culmorum inoculum left in the soil after 1 year at the Bou Salem experimental trial, as analyzed by soil dilution plating and quantitative real-time polymerase chain reaction (qPCR). 

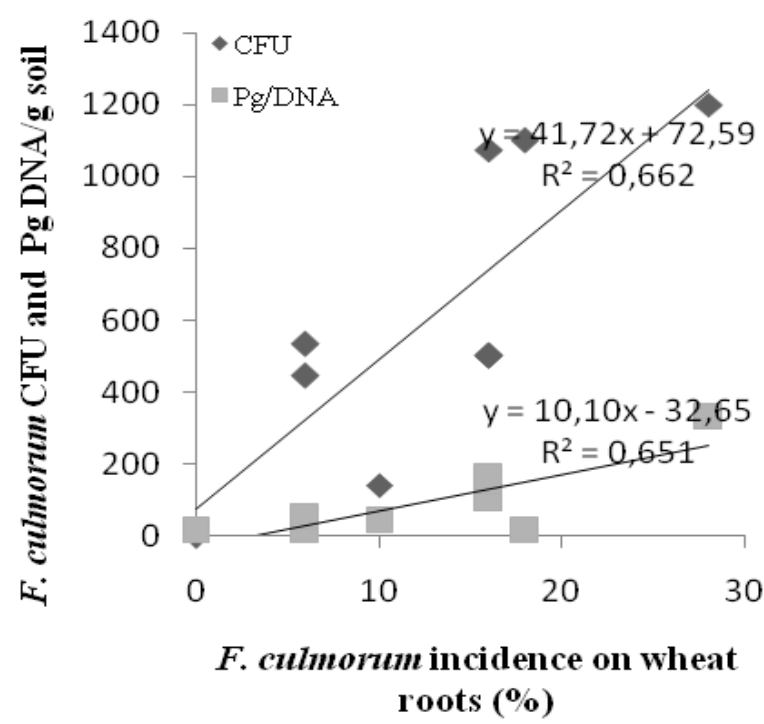

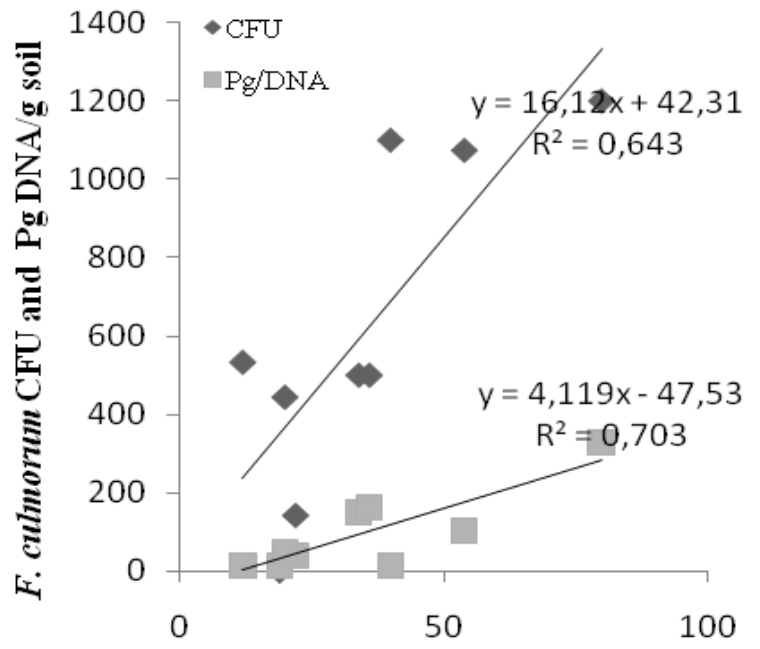

F. culmorum incidence on wheat stem bases $(\%)$

Figure 8. Correlations between Fusarium culmorum incidence (\%) on wheat roots (A) and stem bases (B) and inoculum levels of F. culmorum left in the soil after 1 year, for three demonstration trials at Fernana, Tunisia.

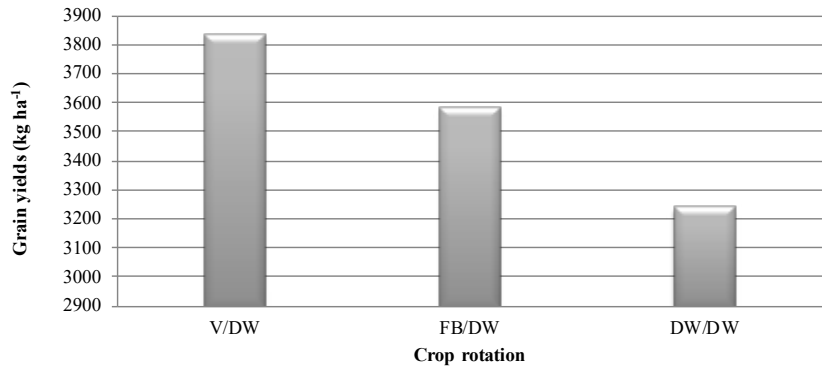

Figure 9. Mean grain yields $\left(\mathrm{kg} \mathrm{ha}^{-1}\right)$ of durum wheat harvested after different rotation crops ( $\mathrm{DW}=$ durum wheat, $\mathrm{FB}=$ faba bean, $\mathrm{V}=$ vetch), from three demonstration trials at Fernana, Tunisia, during the two cropping seasons 2013/14 and 2014/15.

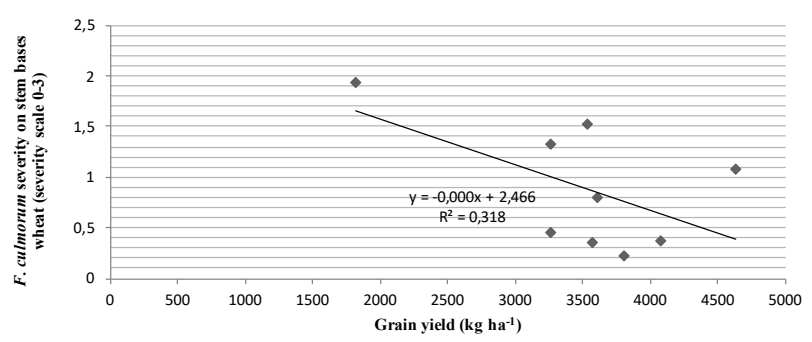

Figure 11. Correlation between disease severity index (scale 0-3) and grain yield $\left(\mathrm{kg} \mathrm{ha}^{-1}\right)$ of durum wheat harvested from three demonstration trials at Fernana, Tunisia.

\section{DISCUSSION}

In this study effects of previous crops on inoculum levels of F. culmorum in soil, development of FFRR, and yield parameters of durum wheat were evaluated in

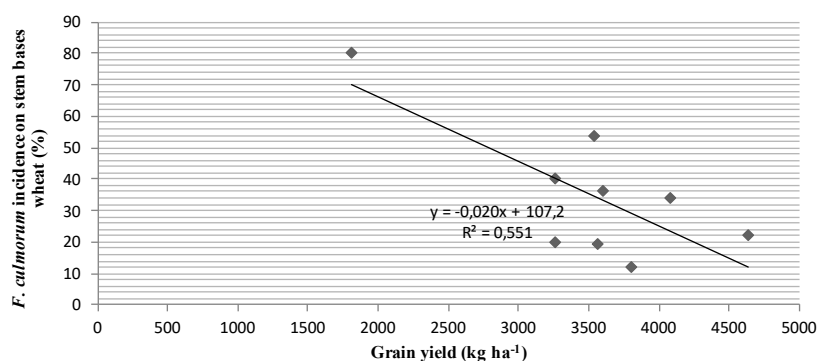

Figure 10. Correlation between Fusarium culmorum incidence (\%) on wheat stem bases and grain yields $\left(\mathrm{kg} \mathrm{ha}^{-1}\right)$ of durum wheat harvested from three demonstration trials at Fernana, Tunisia.

Tunisian farming conditions. Data were collected from an experimental trial, and from demonstration trials established in three farmer's fields.

Inoculum levels of F. culmorum in the soil were quantified using two methods, soil dilution plating and qPCR. Both methods showed the dominance of $F$. culmorum in the upper $10 \mathrm{~cm}$ soil layers of the trial sites. Fusarium pseudograminearum, which has been isolated in other studies from Tunisia (Gargouri et al., 2001, 2007; Chekali et al., 2016), was not detected in the present study. However, this is not surprising since it has been demonstrated that $F$. pseudograminearum is restricted to arid zones in Tunisia (Gargouri et al., 2001), whereas in more humid regions, such as Fernana and Bou Salem where this study was conducted, F. culmorum is the dominant species. These observations have also been confirmed in other regions of the world, including 
the Pacific Northwest of United States of America, and in Australia (Backhouse et al., 2004; Poole et al., 2012).

The results presented here demonstrated that break crops, including faba bean, vetch and fenugreek, reduced the number of propagules of F. culmorum in the soil. These data are confirming previous results which showed that populations of F. culmorum in the soil are affected by the previous crops (Snyder and Nash, 1968; McKenzie and Taylor, 1983). Steinkellner and Langer (2004) also demonstrated that the number of Fusarium CFU in soil was affected by previous crops.

Overall, the results from soil dilution plating were confirmed by qPCR, except for those from Farm 3 in the demonstration trials. At this farm, the amounts of F. culmorum DNA detected were very low, and this may have affected the qPCR analyses. The correlations observed between the two techniques suggest that both are effective for quantifying inoculum levels of $F$. culmorum in field soil. To our knowledge, this is the first report examining correlations between soil dilution and qPCR data for F. culmorum and durum wheat. In addition, this study was the first to measure the levels of $F$. culmorum inoculum in Tunisian soils, and may have been the first to make these assessments in the Mediterranean region.

The amount of F. culmorum DNA in the soil was generally reduced when legumes were used as previous crops before durum wheat. This is consistent with the results of Evans et al. (2010) in south-east Australia, who demonstrated that DNA of F. culmorum in soil was much less after field pea (115 pg DNA g ${ }^{-1}$ ) and greater after durum wheat (974 $\left.\mathrm{pg} \mathrm{DNA} \mathrm{g}^{-1}\right)$ or barley (1,196 pg DNA g $\left.^{-1}\right)$.

The numbers of propagules of F. culmorum detected in the present study ( 0 to $1,974 \mathrm{CFU} \mathrm{g}^{-1}$ of soil) was low compared to other studies. In Austria, Steinkllner and Langer, (2004) reported that inoculum of F. culmorum and $F$. pseudograminearum in the upper $10 \mathrm{~cm}$ layer, ranged between 0 to $8,750 \mathrm{CFU} \mathrm{g}^{-1}$. Similarly, the amounts of $F$. culmorum DNA recorded in the present study were less than those found in Australia (Evans et al., 2010; Halloway et al., 2013).

Development of soil-borne diseases depends on the concentration of the inoculum in the soil (Cook, 1981). Cook (1968) demonstrated that 100 propagules of $F$. culmorum per gram of soil were sufficient to cause damage even when host plants are not under stress. In addition, McKay et al. (2008) suggested guidelines that related DNA amounts of F. culmorum in the soil before sowing to the risk of FFRR and yield losses in bread and durum wheat. They indicated that pre-planting DNA soil amounts less than $100 \mathrm{pg}$ of fungal DNA g-1 of soil for bread wheat and less than $25 \mathrm{pg}$ for durum wheat, would lead to minimal risk of yield losses due to crown rot caused by Fusarium spp.

The low amounts of F. culmorum inoculum in the soil may be explained by several factors. Differences in climatic conditions (Doohan et al., 2003; Xu et al., 2018), tillage methods (Steinkellner and Langer, 2004) and various cultural practices (Klem et al., 2007; Muller et al., 2010; Blandino et al., 2012; Chekali et al., 2016; Hemissi et al., 2018) are known to affect Fusarium populations in the soil. However, the low levels of inoculum observed in the present study were likely related to soil tillage. Lowor no-till are not common practices in Tunisia. Even in the demonstration trials reported here, direct seeding was applied for the first time. Steinkellner and Langer, (2004) found that the total number of CFU of Fusarium spp. was affected by tillage treatment. This agrees with previous studies by Toledo-Souza et al. (2008), who demonstrated that Fusarium inoculum was greater in a notillage system than a conventional one. Paulitz (2006) also showed that FFRR can cause significant damage when no-tillage practices and stubble retention are used. Recently, in Tunisia, Khemir et al. (2018) showed that stubble residue retention on soil surfaces increased $F$. culmorum inoculum levels in plant residues. The impact of no-tillage was also previously reported by Evans et al. (2010), who demonstrated that tillage reduced inoculum levels in soil by burying and promoting rapid degradation of infested plant residues. Furthermore, type and quantity of crop residues left on the soil surface, influence microorganisms and microbial processes in soil (Kandeler et al., 1999). Yi et al. (2002) showed that decomposition of crop residues was associated with a decline in CFU of Fusarium species.

The present study showed that frequency of isolation of F. culmorum from wheat roots and stem bases was affected by the previous crop in both trials, and was reduced by up to $70 \%$. However, the results showed that in general the incidence of the pathogen was greater in stem bases than in roots. Knudsen et al. (1995) reported that FFRR was a consequence of initial stem base infections, while Beccari et al. (2011) and Covarelli et al. (2012) found that the stem bases of durum wheat were more heavily infected by $F$. culmorum compared to the roots. Knight and Sutherland $(2013 ; 2017)$ reported that F. culmorum caused minor necrosis of the primary roots of cereals (durum wheat, bread wheat and barley), but caused serious cortical rot in leaf sheath tissues. These results emphasize the importance of crop residues left on the soil at the level of plant crowns for infection by the Fusarium species and the development of FFRR.

The use of break crops, including faba bean, fenugreek and vetch, decreased the incidence and sever- 
ity of FFRR and increased grain yield in the subsequent durum wheat crop. These results are consistent with previous studies (Felton et al., 1998; Montanari et al., 2006; Zhou and Everts, 2007; Evans et al., 2010; Chekali et al., 2016). Other studies also demonstrated that preceding crops are key factors increasing the risk of Fusarium diseases on cereals (Klem et al., 2007; Muller et al., 2010; Blandino et al., 2012; Chekali et al., 2016). Rotations with chickpea (Felton et al., 1998; Chekali et al., 2016), faba bean (Kirkegaard et al., 2004), pea (Smiley et al., 1996; Evans et al., 2010) or lentil (Chekali et al., 2016) have been reported to reduce the incidence of FFRR. Chekali et al. (2016), showed, in northwest of Tunisia, that faba bean and chickpea used as previous crops could contribute to decreased incidence of infection of roots and stem bases of durum wheat by F. culmorum, and increase grain yields compared to durum wheat as a previous crop.

Rasmussen et al. (2002) hypothesized that this reduction in F. culmorum could be due to the non-host character of legumes, or to their high cellulose contents which increases microbial activity in the soil and leads to decrease of Fusarium spp. survival. In contrast, a high level of infection of wheat by F. culmorum has been reported when monoculture is practiced (Blecharczyk et al., 2006; Kurowsk et Adamiak, 2007; Kraska et Mielniczuk, 2012). In the present study, the Mediterranean forage legume fenugreek was reduced soil inoculum levels of $F$. culmorum by more than $60 \%$, and decreased $F$. culmorum incidence on durum wheat stem bases, compared inoculum and disease incidence in durum wheat monoculture. These results confirm the antifungal activity of fenugreek. Omezzine et al. (2014) assessed in vitro antifungal activity of aqueous extracts from $T$. foenumgraecum, against F. oxysporum $f$. sp. radicis-lycopers$i c i$ and $F$. oxysporum $f$. sp. lycopersici, and reported the antifungal and allelopathic potential of extracts from aerial parts of a Tunisian fenugreek cultivar. Other studies have also reported similar activities (Devasena and Menon, 2003; Oddepally and Guruprasad, 2015; Dharajiya et al., 2016; Sudan et al., 2020). Here, we have demonstrated, for the first time in Tunisia, the beneficial effects of fenugreek as a previous crop to decrease F. culmorum populations in soil and the development of FFRR in durum wheat.

Our results showed positive correlation between $F$. culmorum inoculum concentrations in the soil prior to sowing and subsequent FFRR expression. A negative correlation was also observed between FRRR expression and durum wheat grain yield. These results are similar to those of Smiley et al. (2005), Hollaway et al. (2013) and Chekali et al. (2016). Hollaway et al. (2013) suggest- ed that pre-planting amounts of F. culmorum inoculum and expression of FFRR were positively correlated. Given that control options for FFRR are limited, this information would be valuable for grain producers, to prevent the yield losses caused by these diseases. In Australia, a DNA-based soil testing service (the 'PreDicta ${ }^{\circ} \mathrm{B}$ ' system) was developed in 1997, to improve assessment of risks from root diseases and assist grain producers in planning cropping programmes (Ophel-Keller et al., 2008). Previous applications of this system have been mainly utilized in Australia and the United States (Paulitz et al., 2010; Bithell et al., 2012). This analysis tool is currently not available in Tunisia or in other Mediterranean countries. Our results encourage the use of systematic surveys across years and regions to document Fusarium inoculum levels in soil and FFRR occurrence and severity, and grain yield of durum wheat. This will assist development of a predictive model useful to farmers in Tunisia and the wider Mediterranean region.

In this study, the demonstration trials which involved farmers may impact on extension workers and other grain production stakeholders, to promote adoption of crop rotation as a tool for reducing soil-borne diseases of wheat in Tunisian cropping systems. Further studies would be useful to develop and implement a predictive model based on Fusarium inoculum levels in soil, to assess the risks and estimate the potential yield losses resulting from FFRR. This could be achieved by adjusting cropping sequences and other cultural practices to maximize yields. Our results could be useful for the Mediterranean basin, where FFRR is an endemic disease wherever wheat is cultivated.

\section{ACKNOWLEDGEMENTS}

This research was supported by the Ministry of Higher Education and Scientific Research of Tunisia, and was part of the CANA project CSE-2011-025 (Adapting conservation agriculture for rapid adoption by smallholder farmers in North Africa) financed by the Australian Centre for International Agricultural Research (ACIAR) and managed by the International Centre for Agricultural Research in the Dry Areas (ICARDA). We thank the farmers who collaborated with the researchers in this project.

\section{LITERATURE CITED}

Akinsanmi O.A., Mitter V., Simpfendorfer S., Backhouse D., Chakraborty S., 2004. Identity and pathogenic- 
ity of Fusarium spp. isolated from wheat fields in Queensland and northern New South Wales. Australian Journal of Agricultural Research 55: 97-107.

Anonymous 1, 2019. Middle East and North Africa (MENA) is the most water-stressed region on earth. ICARDA. Available at: https://www.icarda.org/media/ news/middle-east-and-north-africa-mena-mostwater-stressed-region-earth.

Anonymous 2, 2018. Tunisie : Plus de 1 million d'hectares de superficies ensemencées en céréales. WEBMANAGERCENTER. Available at https://www. webmanagercenter.com/2018/03/08/417049/tunisieles-superficies.

Bachta M. S., 2011. La céréaliculture en Tunisie une politique de régulation à repenser. Les notes d'analyse $d u$ CIHEAM 64: 1-19.

Backhouse D., Burgess L.W., 2002. Climatic analysis of the distribution of Fusarium graminearum, F. pseudograminearum and F. culmorum on cereals in Australia. Australasian Plant Pathology 31: 321-327.

Backhouse D., Abubakar A.A., Burgess L.W., Dennis J.I., Hollaway G.J., ... Henry F.J., 2004. Survey of Fusarium species associated with crown rot of wheat and barley in eastern Australia. Australian Plant Pathology 33: 255-261.

Balmas V., 1994. Root rot of wheat in Italy caused by Fusarium graminearum Group 1. Plant Disease 78: 317.

Bankina B., Bimsteine G., Paulvoska L., Paura L., 2019. Effects of soil tillage and crop rotation on the development of wheat stem base diseases. Canadian Journal of Plant Pathology 41: 1-27.

Bateman G. L., 1993. Development of disease symptoms and fungal pathogens on shoot bases in continuous winter wheat. Plant Pathology 42: 595-608.

Bateman G. L., Coskun H., 1995. Populations of Fusarium spp. in soil growing continuous winter wheat, and effects of long-term application of fertilizers and of straw incorporation. Mycological Research 99: 1391-1394.

Batteman G.L., Kwasana H., 1999. Effects of number of winter wheat crops grown successively on fungal communits on wheat roots. Applied Soil Ecology 13: 271-282.

Bateman G.L., Murray G., 2001. Seasonal variation in population of Fusarium species in wheat-field soil. Applied Soil Ecology 18: 117-128.

Bateman G.L., Murray G., Gutteridge R.J., Coskun H., 1998. Effects of method of straw disposal and depth of cultivation on populations of Fusarium spp. in soil and on brown foot rot in continuous winter wheat. Annals of Applied Biology 132: 35-47.
Beccari G., Covoralli L., Nicholson P., 2011. Infection processes and soft wheat response to root rot and crown rot caused by Fusarium culmorum. Plant Pathology 60: 671-684.

Bithell S.L., McKay A., Butler R.C., Herdina, Hartley D., Cromey M.G., 2012. Predicting take-all severity in second-year wheat using soil DNA concentrations of Gaeumannomycesgraminis var. tritici determined with qPCR. Plant Disease 96: 443-451.

Blandino M., Haidukowski M., Pascale M., Plizzari L., Scudellari D., Reyeneri A., 2012. Integrated strategies for the control of Fusarium head blight and deoxynivalenol contamination in winter wheat. Field Crops Research 133: 139-149.

Blecharczyk A., Sierpowski J., Sawinska Z., 2006. Impact of tillage systems on diseases in continuous cropping of winter wheat. Progress Plant Protection 46: 677680.

Burgess L.W., 2011. Foot, crown, and root rots of cereals - insidious diseases of global importance: A Tunisian perspective. 2011. Tunisian Journal of Plant Protection, 6 (Guest Editorial).

Burgess L.W., Wearing A.H., Toussoun T.A., 1975. Surveys of Fusaria associated with crown rot of wheat in eastern Australia. Australian Journal of Agricultural Research 26: 791-799.

Burgess L.W., Backhouse D., Summerell B.A., Swan L.J., 2001. Crown rot of wheat. Pages: 271-294. In: Fusarium. Paul E. Nelson Memorial Symposium. (B.A. Summerell, J.F. Leslie, D. Backhouse, W.L. Bryden, and L.W. Burgess, eds.) APS press, The American Phytopathological Society, St. Paul, Minnesota, USA.

Cassini R., 1981. Fusarium diseases of wheat and corn in Western Europe. Pages 56-63 in: Fusarium: Diseases, Biology, and Taxonomy. (P.E. Nelson, T.A. Toussoun, and R.J. Cook, eds). The Pennsylvania State University Press, University Park, PA, USA.

Chekali S., Gargouri S., Berraies S., Gharbi M.S., Nicol J.M., Nasraoui B., 2013. Impact of Fusarium foot and root rot on yield of cereals in Tunisia. Tunisian Journal of Plant Protection 8: 75-86.

Chekali S., Gargouri S., Rezgui M., Paulitz T. and Nasraoui B., 2016. Impact of previous crops on Fusarium foot and root rot, and on yields of durum wheat in North West Tunisia. Phytopathologia Mediterranea 55: 253-261

Cook R.J., 1968. Fusarium root and foot rot of cereals in the Pacific Northwest. Phytopathology 58: 127-131.

Cook R.J., 1980. Fusarium foot rot and its control in the Pacific Northwest. Plant Disease 64: 1061-1066.

Cook R.J., 1981. Fusarium diseases of wheat and other small grains in North America. Pages: 39-52 In: 
Fusarium. Diseases, Biology and Taxonomy. (P.E. Nelson, T.A. Toussoun, and R.J. Cook, eds). Editions of Pennsylvania State University Press, University Park, PA, USA.

Covarelli L., Beccari G., Steed A., Nicholson P., 2012. Colonization of soft wheat following infection of the stem base by Fusarium culmorum and translocation of deoxynivalenol to the head. Plant Pathology 61: 1121-1129.

Cromey M.G., Parkes R.A., Fraser P.M., 2006. Factors associated with stem base and root diseases of New Zealand wheat and barley crops. Australian Plant Pathology 35: 391-400.

Devasena T., Menon V.P., 2003. Fenugreek affects the activity of beta-glucuronidase and mucinase in the colon. Phytotherapy Research 17: 1088-1091.

Dharajiya D., Jasani H., Khatrani T., Kapuria M., Pachchigar K., Patel P., 2016. Evaluation of antibacterial and antifungal activity of fenugreek (Trigonella foenumgraecum) extracts. International Journal of Pharmacy and Pharmaceutical Sciences 8: 212-217.

Doohan F.M., Brennan J., Cooke B.M., 2003. Influence of climatic factors on Fusarium species pathogenic to cereals. European Journal of Plant Pathology 109: 755-768.

Duke J.A., Reed C.F., Weder P., 1981. Trigonella foenum graecum L. In: Handbook of legumes of world economic importance (J.A. Duke, ed.) New York: Plenum Press.

Evans M.L., Hollaway G. J., Dennis J. I., Correll R., Wallwork H., 2010. Crop sequence as tool for managing populations of Fusarium pseudograminearum and Fusarium culmorum in south-eastern Australia. Australasian Plant Pathology 39: 376-382.

Evidente A., Monoca F.A., Andolfi A., Rubiales D., Motta A., 2007. Trioxazonane, a monosubstituted trioxazonane from Trigonella foenum-graecum root exudates, inhibits Orobranche crenata seed germination. Phytochemistry 68: 2487-2492.

Felton W.L., Marcellos H., Alston C., Martin R. J., Backhouse D., ... Herridge D.F., 1998. Chickpea in wheatbased cropping systems and crown rot in the following crop. Australian Journal of Agricultural Research 49: 401-408.

Gargouri S., Hajlaoui M.R., Guermech A., Marrakchi M., 2001. Identification des espèces fongiques associées à la pourriture du pied du blé et étude de leur répartition selon les étages bioclimatiques en Tunisie. Bulletin OEPP/EPPO Bull 31: 499-503.

Gargouri S., Kammoun L., Guermech A., Hajlaoui M.R., 2007. Evaluation de l'incidence, de la sévérité et des pertes de rendement dues à la pourriture du pied du blé en Tunisie. Annales de l'INRAT 80: 7-20.
Gharbi M.S., El Felah M., 2013. Les céréales en Tunisie : plus d'un siècle de recherche variétale. Annales de l'INRAT 86 : 45-68.

Ghodbane A., Mahjoub M., Djerbi M., Mlaik A., Sharen A.L., 1974. Etude des pertes causées par les pathogènes du blé, Septoria tritici et Fusarium spp. Rapport annuel du ministère de l'agriculture. Office des Céréales, Tunisie 106.

Giorgi F., 2006. Climate change hot-spots'; geophysical Resources Letters, 33: 707-715. GTZ. 2007. Adaptation to climate change: development of a national strategy for agriculture, ecosystems and water resources in Tunisia 2005 to December 2007. 3p

Haouala R., Hawala S., El-Ayeb A., Khanfir R., Boughanmi N., 2008. Aqueous and organic extracts of Trigonella foenum-graecum L. inhibit the mycelia growth of fungi. Journal of Environmental Sciences (China) 20: 1453-1457.

Hemissi I., Gargouri S., Hlel D., Hachana A., Abdi N., Sifi, B., 2018. Impact of nitrogen fertilization on Fusarium foot and root rot and yield of durum wheat. Tunisian Journal of Plant Protection 13: 31-38.

Hogg A.C., Johnston R.H., Dyer A.T., 2007. Applying real time quantitative PCR to Fusarium crown rot of wheat. Plant Disease 91: 1021-1028.

Hollaway G., Evans M., Wallwork H., Dyson C., McKay A., 2013. Yield loss in cereals, caused by Fusarium culmorum and F. pseudograminearum, is related to fungal DNA in soil prior to planting, rainfall and cereal type. Plant Disease 97: 977-982. Available at https://doi.org/10.1094/PDIS-09-12-0867-RE.

Kandeler E., Tscherko D., Spiegel H., 1999. Long-term monitoring of microbial biomass, $\mathrm{N}$ mineralization and enzyme activities of a Chernozem under different tillage management. Biology Fertility Soils 28: 343-351.

Khemir E., Chekali S., Souissi A., Gharbi M.S., 2018. Survival of Fusarium culmorum, causal agent of foot and root rot of cereals, on wheat, barley and oat residues in Tunisia. Annales de L'INRAT 91: 162-172.

Kirkegaard J.A., Simpfendorfer S., Holland J., Bambach R., Moore K.J., Rebetzke G.J., 2004. Effect of previous crops on crown rot and yield of durum and bread wheat in northern NSW. Australian Journal of Agricultural Research 55: 321-334.

Klem K., Vanova M., Hajslova J., Lancova K., Sehnalova M., 2007. A neutral network model for prediction of deoxynivalenol content in wheat grain based on weather data and preceding crop. Plant Soil Environment 53: 421-429.

Knight N.L., Sutherland M.W., 2013. Histopathological assessment of wheat seedling tissues infected by 
Fusarium pseudograminearum. Plant Pathology 62: 679-687.

Knight N.L., Sutherland M.W., 2017. Assessment of Fusarium pseudograminearum and F. culmorum Biomass in seedlings of potential host cereal species. Plant Disease 101: 2116-2122.

Knudsen I.M.B., Hockenhull J., Jensen D.F., 1995. Biocontrol of seedling diseases of barley and wheat caused by Fusarium culmorum and Bipolaris sorokiniana: effects of selected fungal antagonists on growth and yield components. Plant Pathology 44: 467-477.

Köppen W., 1936. The geographic climate system. In: Handbuch der Klimatologie (W. Köppen, R. Geiger, ed.), Gebrüder Borntraeger, Berlin, 1-44 (in German).

Kurowski T., Adamiak E., 2007. Occurrence of stem base diseases of four cereal species grown in long-term monocultures. Polish Journal Natural Sciences 22: 574-583.

Kraska P., Mielniczuk E., 2012. The occurrence of fungi on the stem base and roots of spring wheat (Triticum aestivum L.) grown in monoculture depending on tillage systems and catch crops. Acta Agrobotanica 65: 79-90.

Lamprecht S.C., Marasas W.F.O., Hardy M.B., Calitz, F.J., 2006. Effect of crop rotation on crown rot and the incidence of Fusarium pseudograminearumin wheat in the Western Cape, South Africa. Australian Plant Pathology 35: 419-426.

Leslie J.F., Summerell B.A., 2006. The Fusarium Laboratory Manual. Blackwell Publishing, 388 pp.

McKay A., Roget D., Hannam R., Ophel Keller K., 2008. Root Disease Risk Management Resource Manual. PIRSA Publishing: Adelaide.

McKenzie F., Taylor G.S., 1983. Fusarium populations in British soils relative to different cropping practices. Transactions of the British Mycological Society 80: 409-413.

Mergoum M., Braun H.J., Nicol J., Bagci A., Ekiz H., ... Keser M., 2000. Screening wheat for root rot disease in WANA region. Page 186. In: Abstracts of the 6th International Wheat Conference, 4-9 June, 2000, Budapest, Hungary.

Montanari A., Innocenti G., Toderi G., 2006. Effects of cultural management on the foot and root disease complex of durum wheat. Plant Pathology 88: 149156.

Muller M.E.H., Brenning A., Verch G., Koszinski S., Sommer M., 2010. Multifactorial spatial analysis of mycotoxin contamination of winter wheat at the field and landscape scale. Agriculture, Ecosystems \& Environment 139: 245-254.
Oddepally R., Guruprasad L., 2015. Isolation, purification, and characterization of a stable defensin-like antifungal peptide from Trigonella foenum-graecum (fenugreek) seeds. Biochemistry (Moscow) 80: 332342.

Omezzine F., Daami-Remadi M., Ladhari A., Haouala R., 2014. Variation in phytochemical content and antifungal activity of Trigonella foenum-graecum $\mathrm{L}$. with plant developmental stage and ploidy level. South African Journal of Botany 92: 120-125

ONAGRI, 2016: Observatoire Nationale de l'Agriculture, Annuaire statistique 2016. 190 pp. (in French).

Ophel-Keller K., Mckay A., Hartely D., Herdina P., Curran J., 2008. Development of a routine DNA-based testing service for soil borne diseases in Australia. Australian Plant Pathology 37: 243-253.

Paulitz T.C., 2006. Low input no-till cereal production in the Pacific Northwest of the U.S.: The challenges of root diseases. European Journal of Plant Pathology 115: 271-281.

Paulitz T.C., Schroeder K. L., Schillinger W. F., 2010. Soil borne pathogens of cereals in an irrigated cropping system: effects of tillage, residue management, and crop rotation. Plant Disease 94: 61-68.

Pemonge J., Pascual-Villalobos M.J., Regnault-Roger C., 1997. Effects of material and extracts of Trigonella foenum-graecum $\mathrm{L}$. against the stored product pests Triboleum castaneum (Herbst) (Coleoptera: Tenebrionidae) and Acanthoscelides obtectus (Say) (Coleoptera: Bruchidae). Journal of Stored Products Research 33: 209-217

Pereyra S.A., Dill-Macky R., 2004. Survival and inoculum production of Gibberella zeae in wheat residue. Plant Disease 88: 724-730.

Poole G.J., Smiley R.W., Paulitz T.C., Walker C.A., Carter A.H., ..., Garland-Campbell K., 2012. Identification of quantitative trait loci (QTL) for resistance to Fusarium crown rot (Fusarium pseudograminearum) in multiple assay environments in the Pacific Northwestern US. Theoretical and Applied Genetics 125: 91-107.

Rasmussen P.H., Knudsen I.M.B., Elmholt S., Jensen D.F., 2002. Relationship between soil cellulotytic activity and suppression of seeding blight of barley in arable soils. Applied Soil Ecology 19: 91-96.

Rossi V., Cervi C., Chiusa G., Languasco L., 1995. Fungi associated with foot rots on winter wheat in northwest Italy. Journal of Phytopathology 143: 115-119.

Sitton J.W., Cook R.J., 1981. Comparative morphology and survival of chlamydospores of Fusarium roseum 'Culmorum' and 'Graminearum'. Phytopathology 71: 85-90. 
Slama A., Ben Salem M., Ben Naceur M., Zid E., 2005. Les céréales en Tunisie: Production, effet de la sécheresse et mécanismes de résistance. Sècheresse 16: 225-229 (in French).

Smiley R.W., Gourlie J.A., Easly G.S., Patterson L.M., Whittaker R.G., 2005. Crop damage estimates for crown rot of wheat and barley in the Pacific Northwest. Plant Disease 89: 595-604.

Smiley R.W., Patterson L.M., 1996. Pathogenic fungi associated with Fusarium foot rot of winter wheat in the semiarid Pacific Northwest. Plant Disease 80: 944-949.

Smiley R.W., Patterson L.M., Shelton C.W., 1996. Fungicide seed treatments influence emergence of winter wheat in cold soil. Journal of Production Agriculture 9: 559-563.

Snyder W.C., Nash, S.M., 1968. Relative incidence of Fusarium pathogens of cereals in rotation plots at Rothamsted. Transactions of the British Mycological Society 51: 417-425.

Steinkellner S., Langer I., 2004. Impact of tillage on the incidence of Fusarium spp.in soil. Plant and Soil 267: $13-22$.

Sudan P., Goswami M., Singh J., 2020. Antifungal potential of fenugreek seeds (Trigonella foenum-graecum) crude extracts against Microsporum gypseum. International Journal of Research in Pharmaceutical Sciences 11: 646-649.

Toledo-Souza E.D., Silveira P.M., Lobo J.M., Café Filho A.C., 2008. Soil Density and Soil Pathogens Survival. Pesquisa Agropecuária Brasileira 43: 971-978.

Van Wyk P.S., Los O., Rheeder J.P., Marasas W.F.O., 1987. Fusarium species associated with crown rot of wheat in the Humansdrop District, Cape Province. Phytophylactica 19: 343-344.

Vicente-Serrano S.M., 2006. Spatial and temporal analysis of droughts in the Iberian Peninsula (1910-2000). Hydrological Sciences Journal 51: 83-97.

Wallwork H., Butt M., Cheong J.P.E., Williams K.J., 2004. Resistance to crown rot in wheat identified through an improved method for screening adult plants. Australian Plant Pathology 33: 1-7.

Wisniewska H., Kowalczyk K., 2005. Resistance of cultivars and breeding lines of spring wheat to Fusarium culmorum and powdery mildew. Journal of Applied Genetics 46: 35-40.

Xu F., Yang G., Wang J., Song Y., Liu L., Zhao K., Li Y., Han Z., 2018. Spatial distribution of root and crown rot fungi associated with winter wheat in the north China plain and its relationship with climate variables. Frontiers in Microbiology 9: 1054.

Yi C., Kaul H.-P., Kübler E., Aufhammer W., 2002. Populations of Fusarium graminearum on crop residues as affected by incorporation depth, nitrogen and fungicide application. Journal of Plant Diseases and Protection 109: 252-263.

Zadoks J.C., Chang T.T., Konzak C.F., 1974. A decimal code for the growth stages of cereals. Weed Research 14: 415-421.

Zhou W.G., Everts K.L., 2007. Effects of host resistance and inoculum density on the suppression of Fusarium wilt of watermelon induced by hairy vetch. Plant Disease 1: 92-96.

Zia T., Siddiqui I.A., Nazrul-Hasnain., 2001. Nematicidal activity of Trigonella foenum-graecum L. Phytotherapy Research 15: 538-540. 